\title{
Microfinance Institutions and the Core Poor in Bangladesh: A Review of Their Operations
}

\author{
Taiwo Soetan
}

\begin{abstract}
Instructor, Dept. of Applied Commerce and Management Education, School of Business \& Applied Arts, Red River College, Winnipeg, Canada R3H 0J9

*Corresponding Author: tsoetan@rrc.ca
\end{abstract}

Copyright (C) 2014 Horizon Research Publishing All rights reserved.

\begin{abstract}
This paper presents the findings of a study that investigated the impact of Microfinance Institutions in Bangladesh on the core poor i.e. those living on less than $\$ 1 \mathrm{USD} /$ day and the correlation between the presence of these institutions and poverty in the five Divisions that were examined in the country. Bangladesh is one of the most populous countries in the world with a high level of poverty. This study looked into the operations of these Microfinance Institutions between 1995 and 2005 to establish the correlation between their presence and the poverty level in the locations where they have a strong presence and a weak presence. The study looked into the efforts of Microfinance institutions in poverty alleviation to see if they focused solely on the poor or also catered to the challenges of the core (extremely) poor people that had no valuable possessions or collaterals to obtain loans from them in addition to examining the support of the top three Microfinance Institutions for the vulnerable especially poor women in terms of empowerment in the period under review. This paper concludes with implications of the presence of microfinance institutions for poverty reduction in a geographical location and recommendations for further research.
\end{abstract}

Keywords Microfinance Institutions, Bangladesh, Core poor, Poverty alleviation, Growth

\section{Introduction}

Microfinance is the provision of credit or finance in small amounts to poor households. The provision of credit to the poor has become an important device in efforts to alleviate poverty in many developing countries. Andrews \& Craine (2009) stated that microfinance can be broadly defined as the provision of small-scale financial services to the poor such as savings deposits, credit and other financial services. Kirkpatrik et al (2002) also stated that microfinance involves the provision of financial services which includes credit, savings and insurance products to low income groups while the Canadian International Development Agency, CIDA (2002) defined microfinance as "the provision of financial services, such as savings, credit, payment transfers, and insurance to the poor, so they can smooth their income, invest in economic opportunities, increase their assets, cope with emergencies, and plan for the future." Kota (2007) stated that half of the world's population, almost three billion poor people lacked access to traditional banking services and they form a ready market for microfinance institutions (MFIs).

Many countries have established microfinance programs with the main aim of reducing poverty through the provision of small amounts of credit to the poor, and generation of self-employment in income-earning activities. Furthermore, several international donor agencies and organizations have also being paying increased attention to MFIs through increased funding of their activities in low-income countries. Some of these organizations and donors include Accion international, Women's world Banking, United States Agency for International Development (USAID), Canadian International Development Agency (CIDA), International Fund for Agricultural Development (IFAD), Swedish International Development Agency (SIDA), and Norwegian Agency for International Development (NORAD).

Khandker (1998) stated that The World Bank Group has also been increasing its contribution to the growth of MFIs through the establishment of the Consultative Group to Assist the Poorest (CGAP). Amongst the several objectives of the CGAP is the strengthening of the MFIs by providing grants to support efforts aimed at extending banking services to the poor. It also seeks to develop standards and guidelines for the operations of the MFIs.

Activities of MFIs globally vary according to the region that does the funding. According to a World Bank (1996) report, a worldwide inventory of microfinance programs showed that over one thousand MFIs and non-governmental organizations provide microfinance to the poor in 101 developing countries. The report further showed that 206 MFIs in the 101 countries studied, held over \$7 billion USD in outstanding loans and \$19 billion USD in deposits. The report stated further that over $55 \%$ of these MFIs served 
more women than men and more than $60 \%$ of the institutions studied practised group based lending. The report concluded that MFI funding is regionally concentrated with about $76 \%$ of total loans disbursed in Asia, 21\% in Latin America and just 3\% in Africa. The share of donor funding also varies regionally with donors providing $55 \%$ of the funds in Latin America, $47 \%$ in Asia and 39\% in Africa.

\subsection{Research Question}

The question that will be addressed in this study is whether MFIs reached the core poor i.e. those earning less than $\$ 1 \mathrm{USD} /$ day in Bangladesh. (i.e. Did the MFIs in Bangladesh reach the core poor in the period under review i.e. 1995-2005 or not?). And if they did not, why? If they did, did they have any positive impact at all on the core poor? Contrary to arguments made by several authors that MFIs serve only the not too poor e.g. Hulme \& Mosley (1996), and that their impact on the core poor is insignificant, Shamsuddoha \& Azad (2004), the MFIs do serve the core poor and have had impact amongst the core poor as they have had on the not too poor. This study indicates that the rise in the income level of the core poor has been higher in divisions that have a stronger presence of MFIs than those with a weaker presence and this seems to suggest the positive effect of the MFIs.

\subsection{Brief information on Bangladesh}

The World Bank (2005) country data report for Bangladesh showed that the country was the $7^{\text {th }}$ most populous country, and is amongst the most densely populated countries in the world with a high poverty rate. The report stated further that the country has made considerable progress in the areas of literacy, gender parity and reduction of population growth.

The World Development Indicator-WDI (2007), showed that the country had a population of about 158 million people with the rural population put at over 115 million representing over $73 \%$ of the total population. The report further showed that the life expectancy at birth for males is 63 years and females 65 years, while the population growth rate was put at $2 \%$. The WDI (2005) report showed that $81 \%$ of the total population lives on less than $\$ 2 \mathrm{USD} /$ day. The United Nations Data Report (2005) put the population of the country below the poverty line at $40.0 \%$. Based on the information above, it is obvious that the country needs to come up with innovative methods to fight the problem of poverty that is ravaging almost half of the country's population.

\subsection{Microfinance in Bangladesh}

The development of MFIs in Bangladesh began in the late 1970 's when the poverty issues in the country needed to be addressed following the country's independence. Since then, MFIs have flourished, with many donor institutions contributing to its growth through the provision of financial and technical support to the sector. The MFIs in Bangladesh are some of the largest in the world and they are best known for their pioneering role in the provision of large scale microfinance services. Shamsuddoha \& Azad (2004).

Bangladesh was the first country to introduce microfinance on a large scale. The program started with the Grameen Bank (GB), founded by Muhammad Yunus, a Nobel peace prize winner in 2006. The GB uses microfinance and innovative technologies such as advanced banking systems, network interconnectivity of its various offices to real time online banking transactions etc. to fight poverty and provide opportunities to the world's poorest people. This is done through the provision of tiny loans and financial services to help and empower the poor, especially women, to own businesses and escape poverty. Several other microfinance banks also operate in Bangladesh and have contributed significantly to the success of microfinance in the country. These include the Bangladesh Rural Advancement Committee (BRAC) and Association for Social Advancement (ASA). Yunus (2002) put the number of people that these microfinance institutions in Bangladesh have assisted at 35 million. The access to credit for the poor, through the use of an appropriate institutional structure by the microfinance banks has enabled several poor households to become the architect of their own destiny and thus overcome poverty. Zaman (2004) also stated that the microfinance industry in Bangladesh currently provides access to credit to about 13 million poor households. Daley-Harris (2005) further stated that the MFIs continue to serve an increasing number of both poor and core poor people. A higher percentage of this category also includes women. The percentage of the poorest clients of the top 3 MFIs in the table below ranges from $90 \%$ to $100 \%$, with the poorest women accounting for between $96 \%-100 \%$ of this set of clients.

Table 1.3. showing the top 3 MFIs in Bangladesh and their number of poorest clients

\begin{tabular}{|c|c|c|c|c|c|}
\hline MFIs & $\begin{array}{c}\text { No of 'Poorest' clients as } \\
\text { at } 31 / 12 / 2004\end{array}$ & $\begin{array}{c}\text { No of Active clients as } \\
\text { at } 31 / 12 / 2004\end{array}$ & $\begin{array}{c}\text { \% of Active clients } \\
\text { who are poorest }\end{array}$ & $\begin{array}{c}\text { No of Poorest who } \\
\text { are women }\end{array}$ & $\begin{array}{c}\% \text { of Poorest who are } \\
\text { women }\end{array}$ \\
\hline GB & $4,060,000$ & $4,060,000$ & $100 \%$ & $3,897,600$ & $96 \%$ \\
\hline BRAC & $3,630,000$ & $3,990,000$ & $91 \%$ & $3,630,000$ & $100 \%$ \\
\hline ASA & $2,490,000$ & $2,770,000$ & $90 \%$ & $2,390,400$ & $96 \%$ \\
\hline
\end{tabular}

Source: Daley-Harris (2005)

Note: The poorest clients are those on less than one USD/day when they took their first loan. The active clients are those with outstanding loans. The table does not take into account that some of these borrowers borrow from more than one MFI but it shows that they are servicing the poor households in Bangladesh. 


\section{Literature Review}

Microfinance is a form of financial development primarily focused on alleviating poverty through the provision of financial services to the poor. Stiglitz (1990) emphasised the importance of MFIs in poverty alleviation when he stated that providing the poor with access to financial services is one method of increasing the income and productivity of the poor.

\subsection{Characteristics of Microfinance}

Microfinance provide access to financial and non-financial services to low income people who wish to access credit for starting or developing income generation activity. The various MFIs in Bangladesh have therefore evolved products that suit the needs of these people.

Murray \& Boros (2002) stated that some of the characteristics of these microfinance products are:

- Small size of loans and savings;

- Short term loan (usually up to a year);

- Payment schedules based on frequent deposits;

- Higher interest rates on credit- usually higher than commercial bank rates but lower than money lender's rates;

- Simple application process;

- Short processing periods;

- Consistent payment qualifies for repeat loans with higher amounts etc.

\subsection{MFI Instruments and Poverty Alleviation}

Out of a group of five members, only two of the members are usually eligible in the first instance to take a loan. The group conducts a group observation for a month to observe if the other members will follow the rules laid down by the bank. This includes savings rules in which each member in a group must be able to save at least $\$ 0.68 /$ week. The savings is usually used by the bank to prepare the members to manage their credit. If the first two borrowers repay their loan with interest within the set period of time allocated to them, then the other group members become eligible for the loan. The GB emphasizes savings and also insists that $5 \%$ of the amount of every loan approved must be set aside for a group fund that is managed to provide loans to its members. This rule is now a common practice by most of the MFIs in Bangladesh. Although it was started by the GB, other MFIs in the country soon adopted that approach in granting loans to their clients. Fotabang \& Akanga (2005).

\subsection{Group Based Lending}

Shamsuddoha \& Azad (2004) described it as an approach aimed at assisting both the poor and not too poor with collateral in the rural villages. Group members are jointly held responsible for the repayments of each other's loans and repayments are done weekly. Peer pressure and joint liability is also used to ensure repayment and this style has proved to be very successful. The entire group stands disqualified and ineligible for further loans if a group member defaults thus making the credit worthiness of the borrower dependent on the group members.

\subsection{Individual Lending}

Shamsuddoha \& Azad (2004) stated that under the individual lending approach, loans are provided to individuals without a collective guarantee, on a more flexible term, and the loans are usually big. The clients in this category are not too poor and what the MFIs consider before they give out loans include the financial status of the individual borrowers, and their business potential (i.e. prospects of growing their businesses profitably), government incentives, references from high net-worth individuals in the society etc.

\subsection{Savings Mobilization}

Another major issue that has arisen in recent times that is believed to have an impact on the success of the MFIs in poverty alleviation, is savings mobilization. Harper (2003) and a GB report (2007) countered the long held belief that the poor cannot save. These reports claim that many low income people have the capacity to save and they usually do that through informal channels such as the formation of groups and associations through which people undertake financial activities like lending and saving. Miracle et al (1980) also affirmed that the poor not only save but their savings also have substantial implications for policy and resource mobilization for financial markets and economies. Saving mobilization by MFIs has been shown to boost productive income and employment among the poor which is a positive result. Furthermore, Harper (2003) stated that the process of savings on a regular basis has helped the poor, especially women, in Bangladesh to be able to contribute significantly to an improvement in the quality of their lives, sustain their families, and also enhance their family income.

The GB uses savings as a tool to prepare the borrowers to manage credit. Prospective borrowers make weekly savings deposits which enhance their credit eligibility and each borrower must save the same amount of money through his or her group on a weekly basis. This money is then put into a group fund supervised by the respective groups and it is meant to provide social loans to its members in an emergency. The terms and conditions for the loans are also set by the group. Harper (2003).

\subsection{Human Development and Education}

The MFIs in Bangladesh have increasingly focused on human development that is geared towards the economic and social development of their clients. The focus on human development programs by the MFIs is meant to provide sustainable changes in the lives of the poor especially 
women in Bangladesh. Khan \& Ramahan (2007) stated that the BRAC 2005 report showed that the growing concern that poverty and ignorance are interrelated has caused the MFIs to focus on human development programs as a strategy for removing poverty since poverty reduces the capacity to achieve an improved socio-economic lifestyle.

They further stated that MFIs in Bangladesh have prioritized educational programs because they aim to build a society that is devoid of poverty, illiteracy and diseases. In doing this, the MFIs have products that are targeted at educational and personal development of the poor. The MFIs believe that a well educated and better informed person has a better chance of overcoming poverty compared to an uneducated person. They therefore evolved educational and personal development schemes that will enhance the chances of their clients to develop themselves professionally. The MFIs believe that a well educated person is better placed to overcome poverty which may be caused also by ignorance and lack of empowerment. In doing this, they plan to broaden the educational opportunities of the dis-advantaged and less privileged children and provide them with the necessary financial and emotional support to assist them in their studies and thus be able to fulfil their potentials.

\section{Presentation of the Questions: Micro Finance and the Poor}

Hulme \& Mosley (1996), argued that MFIs in Bangladesh have had no real impact on the core poor while Shamsuddoha \& Azad (2004) have argued that their impact on the core poor do not appear to be as hugely successful as was initially expected. i.e. they have had only a partial success in fighting poverty amongst the core poor. They stated that microfinance is given in most cases to people who have a certain level of resources e.g. land, houses and other assets. Indeed the MFIs require holding some resources, and the group based lending strategy shuts out the core poor. The strategy follows the self selection process of group members who are usually not interested in taking on the core poor as a group member because the failure of the credit worthiness of a group member affects the credit availability of the other members in the group. Kota (2007) also stated that the core poor are avoided by the MFIs because they are riskier and difficult to serve in their dispersed places in rural Bangladesh. Khan \& Ramahan (2007) confirmed this by stating that the poorest districts in Bangladesh which are Nilpharmani, Lalmonirhaat, Dinajpur, Rajshahi and Gazipur do not have any MFI presence.

Core poor people need the most protection against risk and coping with shocks. The not too poor are more likely to take credit for productive opportunities than for protection against risk or coping with shocks. Matin \& Hulme (2003) stated that the core poor in Bangladesh have certain characteristics i.e. they own no land, have no sandals, rely on seasonal wage and/or depend on female members of the household begging. They further stated that the available studies on poverty dynamics that explore poverty-processes and variations in terms of extent and severity suggests that a large part of the poor are transient poor because they move in and out of poverty over time while there still remains a small group of perpetually poor. Poverty is not static and the experience in Bangladesh shows that socio-economic status is related to vulnerability where survival, exposure to risk, defencelessness and self respect are important parameters. Pitt \& Khandker (2001) also stated that Bangladesh experience a seasonality of poverty especially for households that depend mainly on agricultural wage labour. During these period, the core poor that are engaged in farming move above the lower poverty line because they have higher income in the period of harvest. These people however, drop back to the lower poverty line after the period of harvest where their income level drops. Sen (1990) stated that vulnerability removes the difference between the core poor and economically active poor because households can easily move from one category to another which is further complicated by gender and other social variables although it does not remove the fact that they are still poor. The fact that the core poor engaged in farming move above the poverty line temporarily after the harvest does not imply they are no longer poor. Immediately after the harvest season, they relapse back to the core poor state they were initially.

\subsection{MFIs and the Core Poor Districts in Bangladesh}

According to Khan \& Ramahan (2007), the relative absence of MFIs in the poorest districts of Bangladesh which are Nilpharmani, Lalmonirhaat, Dinajpur, Rajshahi and Gazipur goes to show that MFIs have really not served the core poor. Baulch \& Hoddinot (2000) stated that the needs of the core poor are vastly different from those of the not too poor who receive more attention from the MFIs. They stated that both formal and informal discussions with the core poor show that their financial needs were linked to a number of factors such as life cycle need e.g. daughters' marriage, education, emergencies such as floods and personal needs like illness, accidents, or divorce etc and opportunities to acquire assets and livestock. They further stated that another essential need for the core poor was coping with the seasonality of income and expenditure patterns and religious festivals such as Durga puja and Eid. Sebstad \& Cohen (2000) stated that after decades of MFI operations in Bangladesh, "the core poor have truly not been served." The reality they described is different from the general impression of the early 1990's that MFIs were reaching all layers of poor people.

\subsection{Are the Core Poor Really Left Out?}

One of the main arguments given for the failure of MFIs to serve the core poor is the institutional set up of the MFIs. A credit only approach with forced savings tied to the loan keeps the core poor out of the MFIs operations because they find the rules and approach too complex. Rutherford (2000). 
Moreover, Hulme \& Mosley (1997) argued that MFIs avoid this set of people because of their fear that they may not be able to make loan repayment and poor recoveries would reflect on overall performance which is a risk that they are unwilling to take. Khan \& Ramahan (2007) claim that the absence of MFIs in the poorest division in Bangladesh where the core poor are found tend to suggest that the MFIs in the country were only interested in the not too poor people who usually have collaterals and are credit worthy based on group recommendation rather than the core poor who have no collateral or chances of being credit worthy. Several other reports, however, paint a different picture.

On the other hand, the Evaluation study report of the Asian Development Bank (2007) on Bangladesh stated that the MFIs in the country have had significant input in the reduction of poverty in the country. A World Bank (2006) country report stated that although the country still has a long way to go in making poverty a thing of the past, the activities of the more than one thousand MFIs and NGOs coupled with poverty alleviation programs of both the private and commercial banks in combating poverty especially amongst the poorest of the poor is commendable. Although poverty is still endemic in Bangladesh, Khan \& Ramahan (2007) suggested that the activities of the MFIs in the country especially the top four, which are GB, BRAC, ASA and PROSHIKA hugely contributed to the drop in the percentage of the poor in the country from about $49 \%$ in 2000 to $40 \%$ in 2005.

\section{Methodology and Result}

The main objective of this study is to determine whether MFIs are assisting both the core poor and the not too poor or if they are assisting only the not too poor. In doing this, there are basically three questions to be asked. These are:

- Is there evidence that poverty has declined in Bangladesh?

- Has poverty declined more in divisions with more MFIs than low MFIs?

- Is there a difference between those divisions in terms of a decline in core poverty in divisions that have a stronger presence of MFIs than in those with a weaker presence?

I have addressed these questions with the tables below i.e. Tables 4.1, 4.2 and 4.3 respectively. I will discuss the results in Chapter five.

Table 4.1. National Poverty Incidence level (Head-Count Ratio in \%) Showing differences in Poverty levels for both Upper and Lower Poverty lines in the Rural and Urban Areas.

\begin{tabular}{|c|c|c|c|c|c|c|c|}
\hline \multicolumn{2}{|c|}{ Poverty Lines } & 1995 & 2000 & 2005 & $\begin{array}{c}\text { Change from } \\
1995 \text { to 2000 }\end{array}$ & $\begin{array}{c}\text { Change from } \\
2000 \text { to 2005 }\end{array}$ & $\begin{array}{c}\text { Total Change } \\
1995-2005\end{array}$ \\
\hline \multirow{3}{*}{$\begin{array}{c}\text { Upper Poverty } \\
\text { Line }\end{array}$} & Total & 53.1 & 49.8 & 40.0 & -3.3 & -9.8 & -13.2 \\
& Rural & 56.7 & 53.1 & 43.8 & -3.6 & -9.3 & -12.9 \\
\hline \multirow{3}{*}{ Lower Poverty } & Urban & 35.0 & 36.6 & 28.4 & 1.6 & -8.3 & -6.7 \\
Line & Total & 35.6 & 33.7 & 25.5 & -1.9 & -8.2 & -10.1 \\
& Rural & 39.8 & 37.4 & 28.6 & -2.4 & -8.8 & -11.2 \\
& Urban & 14.3 & 19.1 & 14.6 & 4.8 & -4.5 & 0.3 \\
\hline
\end{tabular}

Source: Bangladesh Bureau of Statistics (1995, 2000, \& 2005).

Table 4.2. National Poverty Incidence level (Head-Count Ratio in \%) Showing differences in the Upper Poverty Level between 1995, 2000 , and 2005 in all the divisions in Bangladesh.

\begin{tabular}{|c|c|c|c|c|c|c|c|}
\hline \multicolumn{2}{|c|}{ Division } & 1995 & 2000 & 2005 & Chge - ('95/'00) & Chge - ('00/'05) & Chge - ('95/'05) \\
\hline \multirow{3}{*}{$\begin{array}{c}\text { Barisal } \\
\text { (Strong) }\end{array}$} & Total & 59.9 & 39.8 & 52.0 & -20.1 & 12.2 & -7.9 \\
\hline & Urban & 47.7 & 37.9 & 40.4 & -9.8 & 2.5 & -7.3 \\
\hline & Rural & 60.6 & 40.0 & 54.1 & -20.6 & 14.1 & -6.5 \\
\hline \multirow{3}{*}{$\begin{array}{l}\text { Chittagong } \\
\text { (Strong) }\end{array}$} & Total & 44.9 & 47.7 & 34.0 & 2.8 & -13.7 & -10.9 \\
\hline & Urban & 29.2 & 44.0 & 27.8 & 14.8 & -16.2 & -1.4 \\
\hline & Rural & 47.2 & 48.4 & 36.0 & 1.2 & -12.4 & -11.2 \\
\hline \multirow{3}{*}{$\begin{array}{l}\text { Dhaka } \\
\text { (Strong) }\end{array}$} & Total & 52.0 & 44.8 & 32.0 & -7.2 & -12.8 & -20.0 \\
\hline & Urban & 33.6 & 28.2 & 20.2 & -5.4 & -8.0 & -13.4 \\
\hline & Rural & 58.9 & 52.9 & 39.0 & -6.0 & -13.9 & -19.9 \\
\hline \multirow{3}{*}{$\begin{array}{l}\text { Khulna } \\
\text { (Weak) }\end{array}$} & Total & 51.7 & 51.4 & 45.7 & -0.3 & -5.7 & -6.0 \\
\hline & Urban & 53.3 & 47.1 & 43.2 & -6.2 & -3.9 & -10.1 \\
\hline & Rural & 51.5 & 52.2 & 46.5 & 0.7 & -5.7 & -5.0 \\
\hline \multirow{3}{*}{$\begin{array}{l}\text { Rajshahi } \\
\text { (Weak) }\end{array}$} & Total & 62.2 & 61.0 & 51.2 & -1.2 & -9.8 & -11.0 \\
\hline & Urban & 33.9 & 48.1 & 45.2 & 14.2 & -2.9 & -11.3 \\
\hline & Rural & 65.7 & 62.8 & 52.3 & -2.9 & -10.5 & -13.4 \\
\hline
\end{tabular}

Source: Bangladesh Bureau of Statistics (1995, 2000, \& 2005). 
Table 4.3. National Poverty Incidence level (Head-Count Ratio in \%) Showing differences in Poverty levels for Lower Poverty lines in the Rural and Urban Areas in Bangladesh.

\begin{tabular}{|c|c|c|c|c|}
\hline \multicolumn{2}{|c|}{ Division } & 1995 & 2000 & Chge btw ('95/’00) \\
\hline \multirow{3}{*}{ Barisal } & Total & 43.9 & 28.8 & -15.1 \\
\hline & Urban & 28.9 & 19.5 & -9.4 \\
\hline & Rural & 44.8 & 29.6 & -15.2 \\
\hline \multirow{3}{*}{ Chittagong } & Total & 32.4 & 25.0 & -7.4 \\
\hline & Urban & 12.1 & 23.3 & 11.2 \\
\hline & Rural & 35.3 & 25.3 & -10.0 \\
\hline \multirow{3}{*}{ Dhaka } & Total & 33.0 & 32.0 & -1.0 \\
\hline & Urban & 10.8 & 12.0 & 1.2 \\
\hline & Rural & 41.5 & 41.7 & 0.2 \\
\hline \multirow{3}{*}{ Khulna } & Total & 32.2 & 35.4 & 3.2 \\
\hline & Urban & 25.8 & 27.5 & 1.7 \\
\hline & Rural & 33.2 & 36.8 & 3.6 \\
\hline \multirow{3}{*}{ Rajshahi } & Total & 41.6 & 46.7 & 5.1 \\
\hline & Urban & 19.2 & 32.3 & 13.1 \\
\hline & Rural & 44.4 & 48.8 & 4.4 \\
\hline
\end{tabular}

Source: Bangladesh Bureau of Statistics (1995 \& 2000).

\section{Discussion and Conclusion}

The tables in Chapter four i.e. tables 4.1, 4.2 and 4.3 respectively showed that there was a significant reduction in poverty and a rise in the income level of all the Divisions especially in those with a stronger presence of MFIs in the period compared i.e. 1995, 2000 and 2005. In answering the first question of whether there is evidence that poverty has declined in the country, table 4.1 gives evidence that poverty decreased significantly. The national average between 1995 and 2000 showed an improvement of about 3.3\% for the upper poverty lines and $1.9 \%$ for the lower poverty lines across all the divisions in the country. A further comparison of the 2000 and 2005 data showed a better improvement over the previous years. There was a $9.8 \%$ decline in the upper poverty rates and $8.2 \%$ in the lower poverty rates. The difference between 1995 and 2005 showed a $13.2 \%$ decline in poverty rates. For the rural areas, there was a significant improvement of $12.9 \%$ and $6.7 \%$ for the urban areas for the upper poverty line. The lower poverty line also showed an improvement of $10.1 \%$ for the national average between 1995 and 2005.During this period, poverty rate also declined in the urban areas by $11.2 \%$.

\subsection{Impact of MFIs on the Not Too Poor}

In terms of the upper poverty line i.e. the not too poor, there is a general consensus that MFIs in Bangladesh have helped the not too poor and the evidence in this study supports this claim. Table 4.2 showed that there were large improvements in poverty reduction amongst the not too poor in both the rural and urban areas in all the Divisions in Bangladesh between 1995 and 2005. The table showed that the drop in poverty was higher in areas that had a stronger presence of MFIs compared to those with a weaker presence. The table shows that between 1995 and 2000, poverty decreased by about $9.8 \%$ in the urban areas and $20.0 \%$ in the rural areas in Barisal. The 2000 and 2005 figures however, showed a decline in poverty reduction in this Division. This decline might be due to some natural disasters or other external factors. They do not however, undermine the impact or contribution of the MFIs to poverty reduction.

Furthermore the long-term comparison i.e. 1995 to 2005 showed that poverty declined in this Division by $7.3 \%$ in the urban areas and $6.5 \%$ in the rural areas. Apart from Barisal that showed a decline in poverty reduction between 2000 and 2005, all the other Divisions showed huge improvements in poverty reductions between 1995 and 2000 and between 2000 and 2005. The greatest improvements were however, in the Divisions with a stronger presence of MFIs. Chittagong and Dhaka, with a stronger presence of MFIs had poverty reduced significantly over the years. In Chittagong, poverty was reduced by $16.2 \%$ and $12.4 \%$ in both the urban and rural areas between 2000 and 2005 respectively while the decline in poverty was $1.4 \%$ and $11.2 \%$ between 1995 and 2005 in both the urban and rural areas respectively. In Dhaka, poverty was reduced by $5.4 \%$ and $6.0 \%$ between 1995 and 2000. A further reduction took place between 2000 and 2005 by $8.0 \%$ and $13.9 \%$ in both the urban and rural areas respectively while the reduction between 1995 and 2005 was $13.4 \%$ for the urban areas and $19.9 \%$ for the rural areas. Khulna and Rajshahi the two divisions with the weakest presence of MFIs also experienced a huge drop in their poverty levels. In Khulna, poverty declined by $10.1 \%$ and $5.0 \%$ respectively in both the urban and rural areas between 1995 and 2005 while Rajshahi also had a poverty decline rate of $11.3 \%$ and $13.4 \%$ in both the urban and rural areas between 1995 and 2005.

\subsection{Impact of MFIs on the Core Poor}

Table 4.3 showed a reduction in terms of the number of 
people under the lower poverty line i.e. the core poor between 1995 and 2000 in the Divisions with the highest number of MFIs. The total figures in these Divisions are $15.1 \%, 7.4 \%$ and $1 \%$ for Barisal, Chittagong and Dhaka respectively. These Divisions have a stronger presence of MFIs compared to Khulna and Rajshahi that had a total increase of $3.2 \%$ and $5.1 \%$ respectively during this period.

\subsection{Conclusion}

This study provides some tentative support to the proposition that MFIs in Bangladesh have a positive impact on both the core poor and the not too poor in Bangladesh during the period that was reviewed i.e. 1995-2005. For example, the percentage of the population that fell in both the lower and upper poverty lines was higher in the Divisions with a stronger presence of MFIs than those with a weaker presence. While the evidence in this study cannot demonstrate a causal relationship, it does suggest a correlation between strong MFI presence and higher reductions in poverty. Narayan et al (2007) agreed to this when he stated that MFIs have contributed to the fall in poverty headcount rates in Bangladesh. While there are many other factors apart from MFIs that influence poverty rates, the evidence in this study lends support to a positive connection between a strong presence of MFIs and reduction in core poverty rates. Since this study only reviewed the operations of the MFIs in Bangladesh between the ten year period that spanned from 1995 to 2005 , it is important to see if other studies will come up with similar findings if the research is extended to date and if the presence of MFIs in a particular Division has an impact on the poverty level in that Division too.

\section{REFERENCES}

[1] Andrews, H. \& Craine, S. (2009). "Bright, clean, and affordable: Modern lighting for Microfinance Clients around the Globe." Available at http://lutw.org/wp-content/uploads/lighting-for-microfinance-clients-around-the-world-REEEP. pdf Accessed on October 24, 2013.

[2] Asian Development Bank, Evaluation Study Report (2007). "Effect of Microfinance Operations on Poor Rural Households and the Status of Women." Available at http://www.oecd.org/countries/philippines/39503711.pdf Accessed on October 24, 2013.

[3] Bangladesh Bureau of Statistics (2003). Household income \& expenditure survey, 2000, Bangladesh.

[4] Bangladesh Bureau of Statistics (1998). Household income \& expenditure survey, 1995/96, Bangladesh.

[5] Baulch, B. \& Hoddinot, J. (2000). "Economic Mobility and Poverty Dynamics in Developing Countries, Journal of Development Studies, Vol. 36, Issue 6.

[6] Bryman, A. \& Bell, E. (2003), "Business Research Methods",
(Oxford University Press, Oxford, UK).

[7] CIDA (2002). “CIDA's Microfinance Guidelines: Supporting the Development of Inclusive Financial Systems" Available at http://www.acdi-cida.gc.ca/acdi-cida/acdi-cida. nsf/eng/NAT-83013420-N29\#a3 Accessed on October 24, 2013.

[8] Cheston, S. \& Reeds, L. (1995). "Measuring Transformation: Assessing and improving the impact of microcredit", Journal of microfinance, practitioner and development perspective, vol. 1, No 1, fall, pp. 35.

[9] Coleman, B. E (2001)."Measuring impact of microfinance programs": Finance for the poor, Asian Development Bank, Dec, 2(4), pp. 5-7.

[10] Daley-Harris, S. (2005) State of the Microcredit Summit Campaign Report.

[11] Fotabong, Leonard A. \& Kedju, Akanga F. (2005). "The Impact of Microfinance Institutions on Poverty Reduction in the South-East Province of Cameroon." Masters Thesis, Umeå Business School (USBE), Sweden.

[12] GB, 2007. Annual Report, Grameen Bank, Dhaka, Bangladesh.

[13] Harper, M. (2003), "Microfinance - Evolution, Achievements and Challenges", ITDG Publishing, UK.

[14] Hulme, D. \& Moore, K. (2006).”Why has Microfinance been a policy success in Bangladesh (And Beyond)". Available at http://www.gprg.org/pubs/workingpapers/pdfs/gprg-wps-041 .pdf Accessed on September 6, 2009.

[15] Hulme, D. \& Mosley, P (1996). "Finance against poverty", volumes 1 and 11. London: Routledge.

[16] Hulme, D. \& Mosley, P. (1997). "Finance for the Poor or Poorest? Financial Innovation, Poverty and Vulnerability" in Who Needs Credit? Poverty and Finance in Bangladesh. (Eds) Geoffrey D. Wood \& Iffath A. Sharif. The University Press Ltd. Dhaka.

[17] Khan, M.A \& Rahaman, M.A (2007).”Impact of Microfinance on Living Standards, Empowerment and Poverty Alleviation of Poor People: A Case Study on Microfinance in the Chittagong District of Bangladesh". Available at http://202.198.141.77/upload/soft/0-article/+++ $+++0 / 016$.pdf Accessed on October 18, 2009.

[18] Khandker, S. (1998).’Fighting Poverty with Microcredit." Oxford University Press.

[19] Kirkpatrik, Colin H, Clarke, R. \& Charles, P. (2002). "Handbook on Development Policy and Management." Edward Elgar Publishing.

[20] Kota I. (2007). "Microfinance: Banking for the Poor." Available at http://www.imf.org/external/pubs/ft/fandd/2007/06/basics.ht $\mathrm{m}$ Accessed on October 24, 2013.

[21] Matin, I. \& Hulme, D. (2003). "Programs for the Poorest: Learning from IGVGD Program in Bangladesh.” Available at http://www.bracresearch.org/publications/hulme_matin_pdf. pdf. Accessed on October 26, 2013.

[22] Miracle, M.P, Miracle D.S \& Cohen, L. (1980). "Informal 
Savings Mobilization in Africa," Economic Development and Cultural Change, Vol. 28.

[23] Mosley, P. \& Hulme, D. (1998). "Microenterprise enterprise: Is there a conflict between growth and poverty alleviation?" World Development, 26(5), pp. 783-790.

[24] Murray, U. \& Boros, R. (2002). "A Guide to Gender Sensitive Microfinance." Available at http://www.fao.org/docrep/012/ak208e/ak208e00.pdf Accessed on October 24, 2013.

[25] Nabi, K. A et al in "Grameen Bank and Socio-Economic Changes - A Study of Select Loanees," pp. 10, published by German Cultural Center, Goethe Institute, Dhaka, Bangladesh, February 1997.

[26] Narayan, A, Yoshida N, \& Zaman, H (2007). "Trends and Patterns of Poverty in Bangladesh in Recent Years." Background paper for Poverty Assessment of Bangladesh. World Bank Draft. Available athttp://www.cleancookstoves. org/resources_files/trends-and-patterns-of.pdf Accessed on October 24, 2013.

[27] Pitt, M.M \& Khandker, S.R. (2001). "Credit Programs for the Poor and Seasonality in Rural Bangladesh." Available at http://www.brown.edu/research/projects/pitt/sites/brown.edu .research.projects.pitt/files/uploads/seasonality_\%20paper_1 1-26-01_0.pdf Accessed on October 24, 2013.

[28] Rutherford, Stuart (2000). The Poor and Their Money, Delhi: Oxford University Press, ISBN 0-195-65255-X.

[29] Saunders, M.; Lewis, P.; Tronhill, A. (2007): "Research Methods for Business Students",Fourth Edition, Pearson Education Ltd., pp. 32.

[30] Sebstad, J. \& Cogen, M. (2000). "Microfinance, Risk Management and Poverty." Available athttp://pdf.usaid.gov/ pdf_PNACJ418.pdf Accessed on October 24, 2013.

[31] Sen, A.K. (1990). Gender and Cooperative Conflicts. In Irene Tinker, (Ed.), Persistent Inequalities: Women and World Development. New York: Oxford University Press.

[32] Shamsuddoha, M. \& Azad, A.S.M.S (2004). "Assessing Impact of Microfinance on Poverty Alleviation - Bangladesh Perspective." Available at http://papers.ssrn.com/sol3/papers.cfm?abstract_id=1302291 Accessed on October 24, 2013.

[33] Stiglitz, J. (1990). Peer Monitoring and Credit Markets. The World Bank Economic Review.

[34] Transparency International Report (2008). "Corruption Perception Index in Bangladesh". Available at http://www.ti-bangladesh.org/CPI/CPI2008/CPI2008-compl ete-table.pdf Accessed on November 12, 2009.
[35] United Nations Data Report (2005). "Population below National Poverty Line, Total, Percentage." Available at http://data.un.org/Data.aspx?d=MDG\&f=seriesRowID\%3A5 81 Accessed on October 26, 2013.

[36] Uy, M. \& Zaman, H. (2003). "Microfinance in Bangladesh: Emerging Policy issues", Bangladesh Observer, Dhaka, June 13,2003

[37] World Bank Report (1996). "Sustainable Banking with the Poor: A Worldwide Inventory of Microfinance Institutions." Available http://www-wds.worldbank.org/external/default/WDSConte ntServer/WDSP/IB/1999/08/15/000094946 9904090505228 2/Rendered/PDF/multi page.pdf Accessed on October 24, 2013.

[38] World Bank Report (2005). "The Economics and Governance of Non-Governmental Organizations (NGOs) in Bangladesh." Consultation Draft, Poverty Reduction and Management Sector Unit, South Asia Region. Available at http://www.lcgbangladesh.org/ngos/reports/ngo_report_clien tversion.pdf Accessed on October 24, 2013.

[39] World Bank News Report (2006). "Microfinance Comes of Age." Available at http://web.worldbank.org/WBSITE/EXT ERNAL/NEWS/0,,contentMDK:21153828 pagePK:642570 43 piPK:437376 theSitePK:4607,00.html Accessed on October 24, 2013.

[40] World Development Indicators (2005). Available at http://data.worldbank.org/sites/default/files/wdi05fulltext.pdf Accessed on October 24, 2013.

[41] World Development Indicators (2007). Available at http://siteresources.worldbank.org/DATASTATISTICS/Res ources/WDI07frontmatter.pdf Accessed on October 24, 2013.

[42] Yunus, M. (2002). "Grameen Bank II: Designed to Open New Possibilities.” Dhaka: Grameen Bank.

[43] Zaman, H. (2000)."Assessing the poverty and vulnerability impact of microcredit in Bangladesh: A case study of BRAC", Working papers, 2000 Series, World Bank, New York.

[44] Zaman, H. (2004). "The Scaling-Up of Microfinance in Bangladesh: Determinants, Impact, and lessons". Available at http://papers.ssrn.com/sol3/papers.cfm?abstract_id=625275 Accessed on August 15, 2009.

[45] Zeller, M.; Meyer, Richard L. (2002), "The Triangle of Microfinance - Financial Sustainability, Outreach, and Impact", Published for the International Food Policy Research Institute. The Johns Hopkins University Press, Baltimore and London. 